\title{
Two New Records of Peyssonnelia Species and Sonderophycus cauliferus Comb. Nov. within the Family Peyssonneliaceae (Peyssonneliales) from Korea
}

\author{
So Young Jeong ${ }^{1}$, Danilo E. Bustamante ${ }^{1,2}$, Jin Gyo Lee ${ }^{1}$, Boo Yeon Won ${ }^{1}$, \\ Seung Hee $\mathrm{Kim}^{3}$ and Tae Oh $\mathrm{Cho}^{1, *}$ \\ ${ }^{1}$ Department of Life Science, Chosun University, Gwangju 61452, Republic of Korea \\ ${ }^{2}$ Escuela Profesional de Ingieneria Ambiental, Universidad Nacional Toribio Rodriguez de Mendoza (UNTRM), \\ Chachapoyas, Peru \\ ${ }^{3}$ Department of Dental Hygiene, Gwangju Health University, Gwangju 62287, Republic of Korea
}

\begin{abstract}
Detailed morphological studies and molecular analyses based on plastid-encoded $r b c \mathrm{~L}$ gene sequences were undertaken on Peyssonnelia species, a poorly known genus from Korea. We report new records for the Korean coast, Peyssonnelia harveyana and P. rumoiana. Peyssonnelia harveyana is chiefly characterized by $P$. rubra-type anatomy, closely packed perithallial filaments in firm matrix, hypothallial filaments arranged in parallel rows, thalli with appressed margins, hypobasal calcification, and unicellular rhizoids. Peyssonnelia rumoiana is principally characterized by two vegetative features, hypothallial filaments arranged in a polyflabellate layer, and perithallial filaments arising from the whole upper surface of each hypothallial cell (Peyssonnelia rubra-type anatomy). Our $r b c \mathrm{~L}$ analyses revealed that $P$. harveynana and $P$. rumoiana were placed within a clade of Peyssonnelia. We also propose the new combination, Sonderophycus cauliferus comb. nov., for previous Peyssonnelia caulifera. Phylogenetic analyses revealed that our $S$. cauliferus was placed within a clade of Sonderophycus.
\end{abstract}

Key words : Peyssonnelia rumoiana, Peyssonnelia harveyana, Sonderophycus cauliferus, Rhodophyta

\section{INTRODUCTION}

The Peyssonneliaceae (as the "Squamariaceae Zanardini") was placed in the Gigartinales F. Schmitz (1892). Krayesky (2009) confirmed that the Peyssonneliaceae was a monophyletic group from Gigartinales sensu lato by $r b c \mathrm{~L}$ and LSU rDNA data and he proposed a distinct order, Peyssonneliales. The order Peyssonneliales contains one family, Peyssonneliaceae and 13 genera. Among them, only five genera (Cruoriella P. Crouan \& H. Crouan, Peyssonnelia Decaisne, Polystrata Heydrich, Pulvinia Hollenberg, Sonderophycus Denizot) have been recognized in Japan and

* Corresponding author: Tae Oh Cho, Tel. 062-230-7161, Fax.062-230-7161, E-mail. tocho@chosun.ac.kr
Korea (Nozawa 1968; Yoshida et al. 1990; Yoshida 1998; Kato et al. 2006; Kim et al. 2013).

Red algal genus Peyssonnelia (Peysssonneliaceae, Peyssonneliales) is the largest genus of non-coralline crustose Rhodophyta. It is established by Decaisne (1841) based on P. squamaria (S.G. Gmelin) Decaisne ex J. Agardh. Peyssonnelia is characterized by origin of erect perithallial filaments from the hypothallus, structure of the hypothallus and peri thallus, degree of adherence of the thallus to substratum, location of calcification when present, presence or absence of segmentation in rhizoids, development of sori, the developmental pattern of spermatangial filaments, origin of gonimoblast, position of tetrasporangia, and branching pattern of paraphyses (Kato and Masuda 2002). It cur- 
rently includes 81 species from tropical to warm-temperate regions in the world (Kato and Masuda 2002, 2003; Guiry and Guiry 2017). In Korea, eight species are known: Peyssonnelia boergesenii Weber-van Bosse, $P$. caulifera Okamura, P. conchicola Piccone \& Grunow, P. dubyi P. Crouan \& H. Crouan, P. japonica (Segawa) Yoneshigue, P. orientalis (Weber-van Bosse) Cormaci \& G. Furnari, P. rosenvingei F. Schmitz, and P. rubra (Greville) J. Agardh (Kim et al. 2013). However, most of these species have been recorded as floristic list without taxonomic consideration.

Genus Sonderophycus (Peysssonneliaceae, Gigartinales) was established by Denizot (1968) based on Sonderophycus australis (Sonder) Denizot, currently synonymized to $S$. capensis (Montagne) M.J. Wynne. Krayesky et al. (2009) demonstrated that type species of Sonderophycus capensis (=S. australis) was distinct from Peyssonnelia clade in phylogenetic trees using $r b c \mathrm{~L}$ and LSU rDNA data although they had common crustose thalli. In morphology, Sonderophycus also differs from Peyssonnelia in thallus structure, with longitudinal filaments that diverge to upper and lower surfaces (Womersley and Sinkora 1981).

We collected samples that fit the description of Peyssonnelia and Sonderophycus from east and south coasts of Korea. We observed morphology in detail and compared their phylogenetic relationship based on $r b c \mathrm{~L}$ sequence analysis. In this study, we report Sonderophycus cauliferus comb. nov. and two new records of Peyssonnelia species from Korea.

\section{METERIALS AND METHODS}

\section{Morphology}

Plants were collected from the coasts of Korea. Fresh samples were removed from bedrock, shells, or seaweeds using a chisel and hammer. Samples were preserved in 4-5\% formalin/seawater for morphological examination. Samples were completely decalcified in $0.6 \mathrm{M}$ nitric acid for a minimum of 30 minutes, rinsed with distilled water, and stained using a $3: 7$ mixture of $1 \%$ aqueous aniline blue and glycerin for more than 30 minutes. For detailed morphology, sections of thallus (5-10 $\mu \mathrm{m}$ thickness) were prepared using an embedding matrix (O.C.T.; CellPath, Ltd., Newtown, Wales, UK) and a freezing microtome (Shandon
Cryotome FSE; Thermo Shandon, Ltd., UK). Photomicrographs were taken using an Olympus microscope (BX51TRF; Olympus, Tokyo, Japan) and an Olympus DP71 camera. Permanent slides were mounted in karo syrup (70\%). Representative specimens examined in this study are deposited in the National Institute of Biological Resources (NIBR) and herbarium of Chosun University (CUK), Korea.

\section{Molecular study}

Samples were cleaned in autoclaved seawater under a dissecting microscope and were preserved in silica gel for molecular analysis. Genomic DNA was extracted using a NucleoSpin Plant II Kit (Macherey-Nagel, Düren, Germany), following manufacturer's instructions. Polymerase chain reaction (PCR) was conducted in $30 \mu \mathrm{L}$ reactions that contained 4-8 $\mu \mathrm{L}$ genomic DNA or $10 \mu \mathrm{L}$ diluted genomic DNA (1 : 10), $1 \mu \mathrm{L} 10$ pmols forward and reverse primers, and HelixAmp Ready-2x-Go Series (NanoHelix Co., Ltd., Daejeon, Korea). The $r b c \mathrm{~L}$ was amplified using primer combinations F57-R1150 and F993-RrbcStart (Freshwater and Rueness 1994) and purified with PCRquick-spin ${ }^{\mathrm{TM}}$ PCR product purification kit (iNtRON Biotechnology, Inc. Seongnam, Korea). Cycle sequencing was conducted with amplification primers. Sequences were determined by using an ABI Prism 3100 Genetic Analyzer (PE Applied Biosystems, Foster City, CA, USA). The $r b c \mathrm{~L}$ sequences generated in this study were deposited in EMBL/GenBank under accession numbers MF668134 for Peyssonnelia harveyana, MF 668135 for P. rumoiana, and MF668136 for Sonderophycus cauliferus. Chondrus crispus (U02984) was selected as outgroup. These sequences and other nucleotide sequences from GenBank were aligned using Clustal W (Thompson et al. 1994) and manually corrected using MEGA5 (Tamura et al. 2011). Maximum likelihood analyses were conducted in MEGA5, using 1000 bootstrap replications and the GTR + $\Gamma+\mathrm{I}$ model, and Bayesian inference was conducted using MrBayes 3.1.2 (Huelsenbeck and Ronquist 2001; Ronquist and Huelsenbeck 2003). Markov chain Monte Carlo runs were conducted for 2 million generations, each with one cold chain and three heated chains using the GTR $+\Gamma+\mathrm{I}$ evolutionary model and sampling and printing every 1000 generations. Summary trees were generated using a burn-in value of 800 


\section{RESULTS AND DISCUSSION}

\section{Phylogenetic analyses}

The $1228 r b c \mathrm{~L}$ bp portion of the 1467-bp $r b c \mathrm{~L}$ gene (83.7\% sequenced) sequenced for Peyssonnelia harveynana, P. rumoiana, and Sonderophycus cauliferus. Phylogenetic analyses revealed that $P$. harveynana and $P$. rumoiana were placed within a clade of Peyssonnelia (Fig. 1). However, $S$. cauliferus ( = P. caulifera) was placed within a clade of Sonderophycus (Fig. 1).

Phylogenetic analyses revealed Peyssonnelia harveynana differs from $P$. orientalis by $7.6-7.8 \%$ and $P$. inamoena by 8.1-8.3\% gene sequence divergence respectively and $P$ eyssonnelia rumoiana differs from P. armorica by $8.9-9.2 \%$ gene sequence divergence respectively. Sonderophycus cauliferus $(=P$. caulifera) differs from $S$. coriaceus by $9.5-$ $9.8 \%$ gene sequence divergence respectively.

\section{Morphological observations}

Class Florideophyceae Cronquist, 1960 진정홍조강

Order Peyssonneliales Krayesky, Fredericq \& J. N.

Norris, 2009 바다표고목

Family Peyssonneliaceae Denizot, 1968 바다표고과

Genus Peyssonnlia Decaisne, 1841 바다표고속

Peyssonnelia harveynana P. Crouan \& H. Crouan ex J. Agardh, 1851 붉은바다표고(신칭) (Fig. 2A-D)

Synonyms: Peyssonnelia adriatica Hauk 1882, Cruoriella adriatica (Hauk) De Toni 1905.

Material examined: NIBRRD0000000214 (deposited in the National Institute of Biological Resources), CUK13191, MF668134, Seongsan beach, Seongsan-eub, Seogyipo-si, Jeju, Korea (332 $27^{\prime} 42.57^{\prime \prime N}, 126^{\circ} 56^{\prime} 20.93^{\prime \prime E}$ ), July 7, 2014, Cho and Jeong, at $1 \mathrm{~m}$ depth by hand.

Description: Crustose thalli solitarily or gregariously growing on pebbles in the intertidal zone, closely adherent to substrata with appressed margins (Fig. 2A), purplish-red, 3-8 mm (partly collected) in diameter, $80-173 \mu \mathrm{m}$ thick excluding nemathecia. Surface of each thallus with weakly marked concentric zones and faint radial lines. Hypothallial filaments arranged in parallel rows in surface view (Fig. 2B), 32-41 $\mu \mathrm{m}$ broad in radiating rows and 10-17 $\mu \mathrm{m}$ long. Perithallial filaments arising somewhat obliquely from the whole upper surface of each hypothallial cell (the P. rubratype anatomy), tightly packed in a firm matrix, 5-8 cells high in the center of the crust (Fig. 2C). The basal cells of the perithallial filaments wider than high, 29-38 $\mu \mathrm{m}$ broad by $12-20 \mu \mathrm{m}$ high, boot-shaped producing two ascending filaments (one simple and one dichotomously branched filament) cells of ascending filament $4-20 \mu \mathrm{m}$ broad by 3-12 $\mu \mathrm{m}$ high (Fig. 2C). Unicellular rhizoids produced frequently from the median region (rarely near the anterior end) of hypothallial cells, $3-12 \mu \mathrm{m}$ broad by $32-95 \mu \mathrm{m}$ long (Fig. 2D).

Habitat: Epilithic on the rock at intertidal zone.

World Distribution: Europe (Britain, France, Greece, Ireland, Italy, Portugal, Spain, Turkey), Atlantic Islands, South America (Argentina, Chile), Africa (Angola, Egypt, Tunisia), Indian Ocean Islands, Asia (Korea, Japan), Antarctic and the Sub Antarctic islands (Guiry and Guiry 2017).

Identifier: Tae Oh Cho and So Young Jeong.

Remarks: Peyssonnelia harveyana was originally described by Crouan and Crouan (1851) from France. This species has been widely reported worldwide. Our collections match the protologue of Peyssonnelia harveyana in most characteristics from the British Isles (Irvine and Maggs 1983) and Japan (Kato et al. 2005). We add this species as $P$. harveyana in list of Korean macroalgal flora.

\section{Peyssonnelia rumoiana Kato \& Masuda, 2003}

바위바다표고(신칭) (Fig. 3A-E)

Material examined: NIBRRD0000000213 (deposited in the National Institute of Biological Resources), CUK10494, MF668135, Gampo harbor, Gampo-eub, Gyeongju-si, Gyeongsangnam-do, Korea (35 $48^{\prime} 05.36^{\prime \prime} \mathrm{N}, 129^{\circ} 30^{\prime} 27.46^{\prime \prime}$ E), July 5, 2013, Cho and Jeong, at $1 \mathrm{~m}$ depth by hand.

Description: Crustose thalli solitarily growing on pebbles in the intertidal zone, circular in shape, completely adherent to the substrata with appressed margins (Fig. 3A), bloodred, $0.3-0.8 \mathrm{~mm}$ in diameter, $36-99 \mu \mathrm{m}$ thick excluding nemathecia. Surface of each thallus with weakly marked concentric zones and faint radial lines. Hypothallial filaments comprising a polyflabellate layer (Fig. 3B), 16-21 $\mu \mathrm{m}$ broad in radiating rows and $8-11 \mu \mathrm{m}$ long. Margin composing single cell (Fig. 3C). Perithallial filaments arising somewhat obliquely from the whole upper surface of each hypothallial cell (the $P$. rubra-type anatomy), tightly packed 


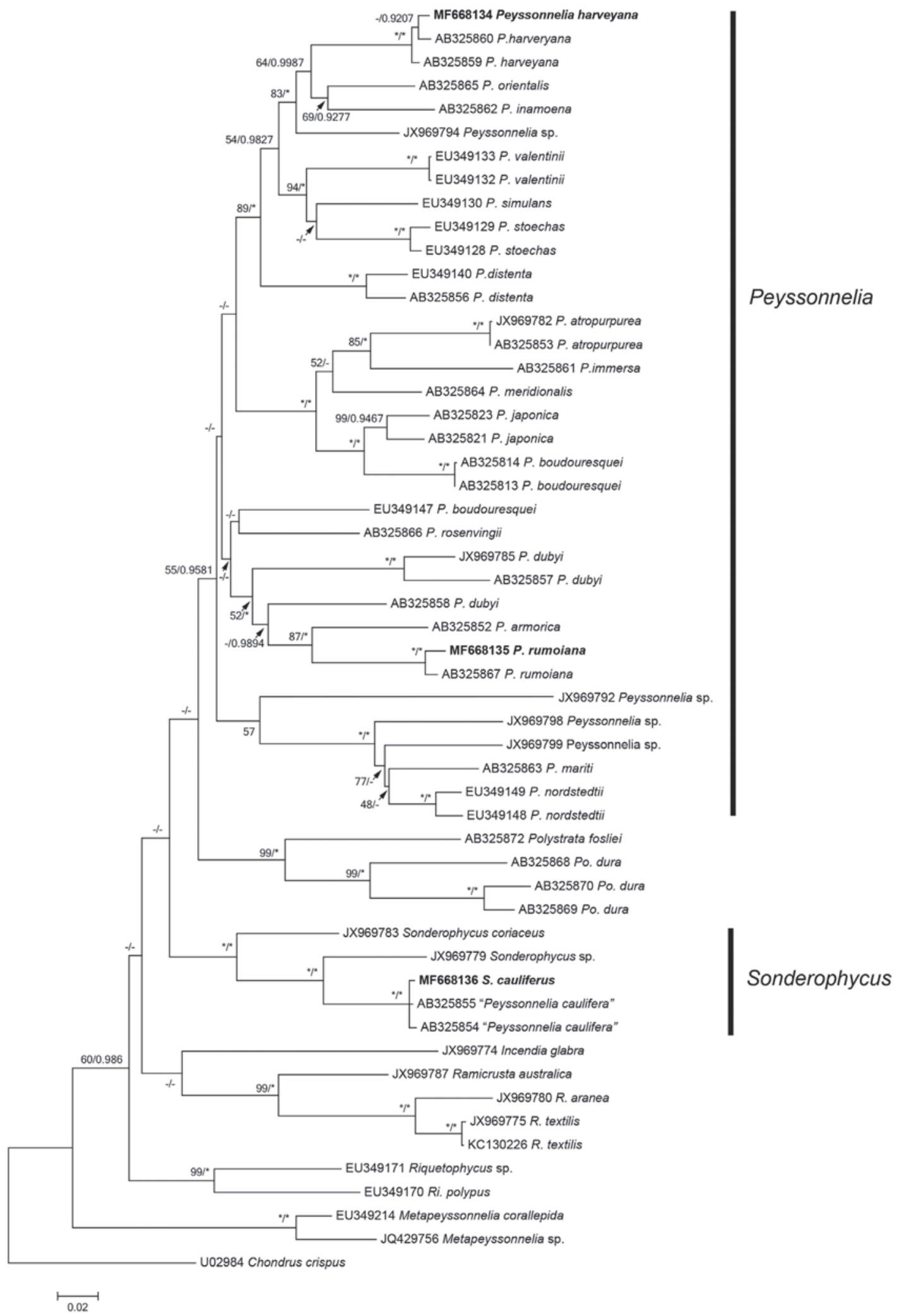

Fig. 1. Phylogenetic tree of species of Peyssonnelia and Sonderophycus based on Maximum-likelihood (ML) analysis with $r b c \mathrm{~L}$ sequences. Values above branches $=$ ML bootstrap (BS) values in $\%>50 /$ Bayesian posterior probabilities (BPP) $>0.75$. Values lower than BS $50 \%$ or BPP 0.75 are indicated by hyphens (-). Values of BS $100 \%$ or BPP 1.00 are indicated by asterisks $\left(^{*}\right)$. 

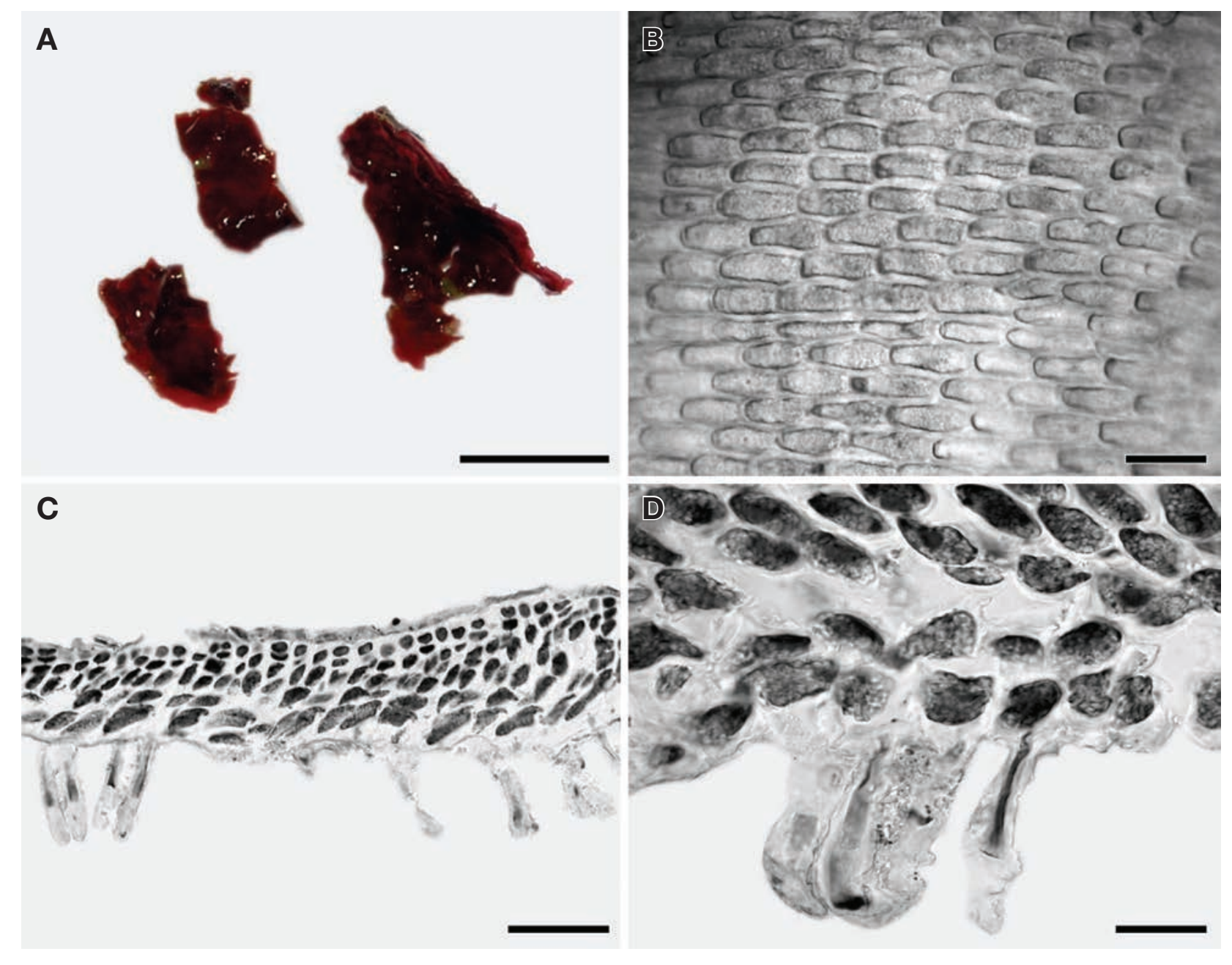

Fig. 2. Peyssonnelia harveyana P. Crouan \& H. Crouan ex J. Agardh. A. Habit with typical crustose thalli; B. Hypothallial filaments arranged in a parallel layer; C. Cross section view showing perithallial filaments that arise from each cell of the hypothallus; D. Unicellular rhizoids developed from the median region or near the anterior end of each hypothallial cell. Scale bars: $\mathrm{A}=5 \mathrm{~mm} ; \mathrm{B}=40 \mu \mathrm{m} ; \mathrm{C}=100$ $\mu \mathrm{m} ; \mathrm{D}=25 \mu \mathrm{m}$.

in firm matrix, 7-13 cells high in the center of the crust (Fig. 3D). Basal cells of the perithallial filaments wider than high 13-19 $\mu \mathrm{m}$ broad by 7-11 $\mu \mathrm{m}$ high, boot-shaped producing two ascending filaments (one simple and one dichotomously branched filament) cells of the ascending filament 3-6 $\mu \mathrm{m}$ broad by $4-14 \mu \mathrm{m}$ high (Fig. 3D). Unicellular rhizoids produced frequently from the anterior region (rarely from median region) of hypothallial cells, $3-5 \mu \mathrm{m}$ broad by $8-15$ $\mu \mathrm{m}$ long (Fig. 3E).

Habitat: Epilithic on the rock at intertidal zone.

World Distribution: Korea, Japan (Guiry and Guiry 2017).

Identifier: Tae Oh Cho and So Young Jeong.

Remarks: Peyssonnelia rumoiana was first described by
Kato and Masuda (2003) from Ogon-miski, Rumoi, Hokkaido of Japan. We collected this species growing on a rock at the intertidal zone from Gampo on the eastern coast of Korea. Our morphological observations agree with the description of Kato and Masuda (2003). We add P. rumoiana in list of Korean algal flora.

Genus Sonderophycus Denizot, 1968 아프리카바다표고속

Sonderophycus cauliferus (Okamura) S.Y. Jeong, B.Y.

Won \& T.O. Cho comb. nov. 자루아프리카바다표고

(신칭) (Fig. 4A-E)

Synonyms: Peyssonnelia caulifera Okamura 1899. 

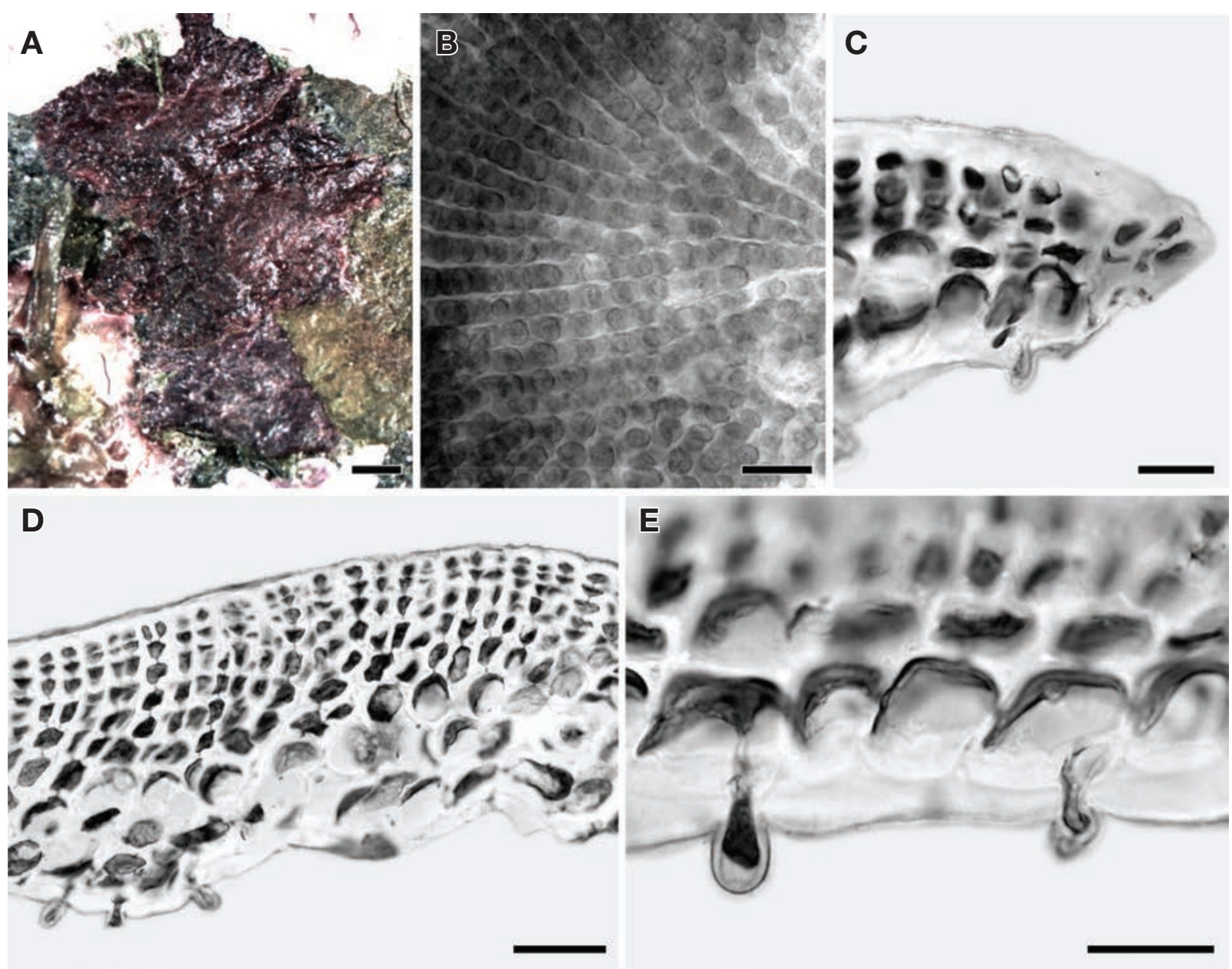

Fig. 3. Peyssonnelia rumoiana Kato \& Masuda. A. Habit with typical crustose thalli; B. Hypothallial filaments arranged in a polyflabellate layer; C. Cross section view of marginal part; D. Cross section view of lower thallus showing perithallial filaments that arise from each cell of the hypothallus; E. Unicellular rhizoids developed from the near the anterior end of each hypothallial cell. Scale bars: $\mathrm{A}=2 \mathrm{~mm} ; \mathrm{B}, \mathrm{C}=20 \mu \mathrm{m} ; \mathrm{D}=25 \mu \mathrm{m} ; \mathrm{E}=10 \mu \mathrm{m}$.

Material examined: NIBRRD0000000216 (deposited in the National Institute of Biological Resources), CUK13194, MF668136, Geommeolae beach, Udo-myeon, Jeju-si, Jeju, Korea $\left(33^{\circ} 29^{\prime} 49.56^{\prime \prime} \mathrm{N}, 126^{\circ} 58^{\prime} 01.32^{\prime \prime} \mathrm{E}\right)$, November 7 , 2014, Cho and Jeong, at $15 \mathrm{~m}$ depth by scuba diving.

Description: Plants solitarily or gregariously growing on bottom (mollusk or other creeping algae) in subtidal zone, prostrate, thick, cartilaginous, crustose and lobed (Fig. 4A), dark red on upper surface, and pale-red on lower surface. Thalli loosely attached to substrata with detached margins, spreading from a stipe-like, dense interwoven mass of multicellular rhizoids beneath the thallus. Lamina proximally becoming wider and fan-like in appearance, forming layered foliose, to $0.8-1.5 \mathrm{~cm}$ long and to $1.1-1.7 \mathrm{~cm}$ broad, and 103-183 $\mu \mathrm{m}$ thick excluding nemathecia (Fig. 4A). Thallus internally composed of several cell rows that form the dorsal (Fig. 4B) and ventral surfaces. Dorsal surface cells isodiametric, 6-16 $\mu \mathrm{m}$ in dimeter (Fig. 4B). Margin composing one-celled apical cell (Fig. 3C). Internal structure of thallus composed of two layers: a ventral hypothallus and a dorsal perithallus. Basal layer of single cell layer on the lower surface produces perithallial cells and bent basal cells of rhizoids pointing slightly forward (Fig. 4D). Basal layer of perithallus of ascending filaments at angles of $30-40^{\circ}$ in the lower and middle perithallus, with the apical portions of filaments in the upper perithallus bending to a $90^{\circ}$ angle. Perithallial cells elongated in basal layer, isodiametric in upper layer. Basal cells of multicellular rhizoids 

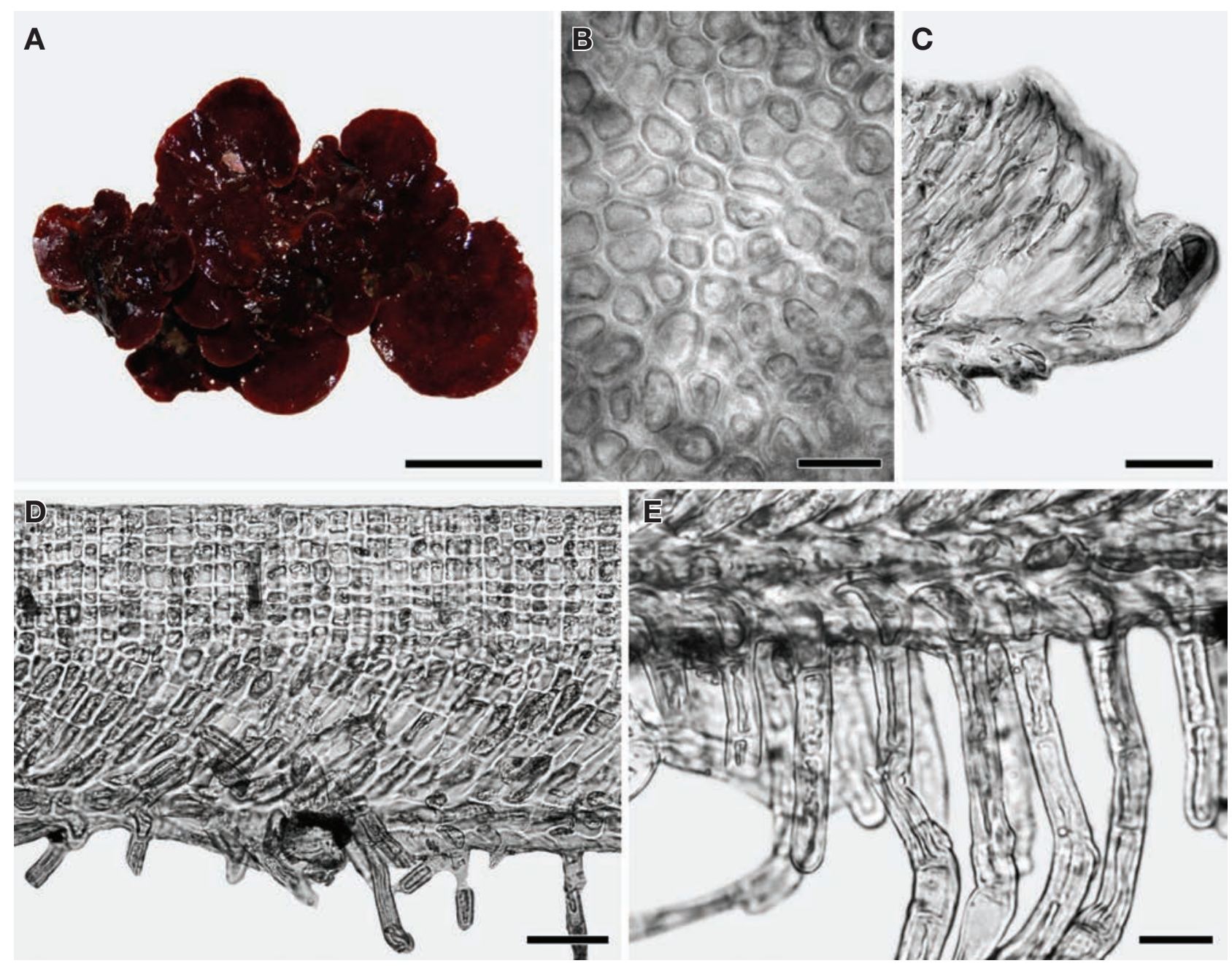

Fig. 4. Sonderophycus cauliferus (Okamura) S.Y. Jeong, B.Y. Won \& T.O. Cho comb. nov. S.Y. Jeong, B.Y. Won \& T.O. Cho. A. Habit with fan-shaped thalli; B. Isodiametric hypothallial filaments on ventral side; C. Cross section view of marginal part; D. Cross section view of lower thallus showing perithallial filaments that arise from each cell of the hypothallus; E. Unicellular rhizoids developed from the median region or near the anterior end of each hypothallial cell. Scale bars: $A=1 \mathrm{~cm} ; \mathrm{B}=20 \mu \mathrm{m} ; \mathrm{C}=50 \mu \mathrm{m} ; \mathrm{D}=25 \mu \mathrm{m} ; \mathrm{E}=10 \mu \mathrm{m}$.

point forward and lie within the blade sheath, $5-12 \mu \mathrm{m}$ broad by $37-89 \mu \mathrm{m}$ long (Fig. 4E).

Habitat: Epilithic on the rock, epiphytic on other algae, epizoic on molluscs at subtidal zone.

World Distribution: Asia (Korea, Japan, Taiwan), Southeast Asia (Vietnam), Pacific Islands (Guiry and Guiry 2017). Identifier: Tae Oh Cho and So Young Jeong.

Remarks: Peyssonnelia caulifera is here transferred to the genus Sonderophycus. Sonderophycus cauliferus was originally reported in Japan and our sequences of S. cauliferus corresponded with $r b c \mathrm{~L}$ data of Japanese samples. Sonderophycus cauliferus shares most of vegetative characters with S. coriaceus, however S. cauliferus differs from S. coria- ceus in shape of ventral cells, with isodiametric cells on dorsal and ventral surface (Krayesky 2009). Reproduction thalli are not observed in this study.

\section{ACKNOWLEDGEMENT}

This study was supported by a grant from the National Institute of Biological Resources (NIBR), funded by the Ministry of Environment (MOE) of the Republic of Korea (NIBR201701204). This research was also supported by Basic Science Research Program through the National Research Foundation of Korea (NRF) funded 
by the Ministry of Education, Science and Technology (2015R1D1A1A01058359) and a grant from Marine Biotechnology Program (20140449 and 20170431) funded by Ministry of Oceans and Fisheries of Korean Government to Tae Oh Cho.

\section{REFERENCES}

Agardh JG. 1851. Species genera et ordines algarum, seu descriptions succinctae specierum, generum et ordinum, quibus algarum regnum constituitur. Volumen secundum: algas florideas complectens. Part 2, fasc. 1.pp. 1-337.

Cronquist A. 1960. The division and classes of plants. Bot. Rev. 26:425-482.

Crouan PL and HM Crouan. 1859. Notice sur quelques espèce et genres nouveaux d'algues marines de la Rade de Brest. Annales des Sciences Naturelles, Botanique, Quatrième Série. 12:288-292.

Decaisne J. 1841. Plantes de I'Arabie Heureuse, recueillies par M. P.-E. Botta et décrites par M. J. Decaisne. Archives du Muséum d'Histoire Naturelle, Paris. 2:89-199, pls. 14-17.

De Toni GB. 1905. Sylloge algarum omnium hucusque cognitarum. Vol. IV. Florideae. Sectio IV. pp. 1523-1973.

Denizot M. 1968. Les algues Floridées encroutantes (à l'exclusion des Corallinacées). Thesé, La boratoire de Cryptogamie, Muséum national d'Histoire naturelle, Paris. pp. 1-310.

Freshwater DW and J Rueness. 1994. Phylogenetic relationships of some European Gelidium (Gelidiales, Rhodophyta) species, based on $r b c \mathrm{~L}$ nucleotide sequence analysis. Phycologia 33:187-194.

Guiry MD and GM Guiry. 2017. AlgaeBase. World-wide electronic publication, National University of Ireland, Galway. http://www.algaebase.org; searched on 31 July 2017.

Hauck F. 1882. Die Meeresalgen Deutschlands und Österreichs. In: Kryptogamen-Flora von Deutschland, Österreich und der Schweiz. Zweite Auflage (Rabenhorst L ed.). vol. 2. pp. 1-112.

Heydrich F. 1905. Polystrata, eine Squamariacee aus den Tropen. Ber Dtsch Bot Ges. 23:30-36.

Hollenberg GJ. 1970. Phycological notes. IV. Including new marine algae and new records for California. Phycologia 9:61-72.

Huelsenbek JP and F Ronquist 2001. MrBayes: Bayesian inference of phylogeny. Bioinformatics 17:754-755.

Irvine LM and CA Maggs. 1983. Peyssonneliaceae. pp. 52-61. In Seaweeds of the British Isles, Vol. 1 Rhodophyta, Part 2A Cryptonemiales (sensu stricto), Palmariales, Rhodyme- niales (Irvine LM ed.). British Museum (Natural History), London.

Kato A and M Masuda. 2002. A morphological study of Peyssonnelia meridionalis (Gigartinales, Rhodophyta), with discussion of spermatangial types within the genus. Phycologia 41:191-198.

Kato A and M Masuda. 2003. A new crustose red alga Peyssonnelia rumoiana (Rhodophyta, Gigartinales) from Japan. Phycol. Res. 51:21-28.

Kato A, M Masuda and H Kawai. 2005. New records of Peyssonnelia armorica and Peyssonnelia harveyana (Rhodophyta, Gigartinales) from Japan. Phycol. Res. 53:266-274.

Kato A, M Baba, H Kawai and M Masuda. 2006. Reassessment of the little-known crustose red algal genus Polystrata (Gigartinales), based on morphology and SSU rDNA sequences. J. Phycol. 42:922-933.

Kim HS, SM Boo, IK Lee and CH Sohn. 2013. National List of Species of Korea Marine Algae Seoul: Jeonghaegsa. pp. 194-196.

Krayesky DM, JN Norris, PW Gabrielson, D Gabriel and S Fredericq. 2009. A new order of red algae based on the Peyssonneliaceae, with an evaluation of the ordinal classification of the Florideophyceae (Rhodophyta). Proc. Biol. Soc. Wash. 122:364-391.

Nozawa Y. 1968. Systematic anatomy of the Squamariaceae in the southern islands of Japan (1) Cruoriella elegans sp. nov. Phycol. Res. 16:44-52.

Okamura K. 1899. Contributions to the knowledge of the marine algae of Japan. III. Botanical Magazine, Tokyo. 13:2$10,35-43$

Ronquist F and JP Huelsenbeck. 2003. MrBayes 3: Bayesian phylogenetic inference under mixed models. Bioinformatics 19:1572-1574.

Schmitz F. 1892. (6. Klasse Rhodophyceae) 2. Unterklasse Florideae. pp. 16-23. In A. Engler, ed., Syllabus der Vorlesungen über specielle und medicinisch-pharmaceutische Botanik. Grosse Ausgabe [Edition 1]. Gebr. Borntraeger, Berlin. pp. 1-184.

Tamura KD, D Peterson, N Peterson, G Stecher, M Nei and S Kumar. 2011. MEGA5: molecular evolutionary genetics analysis using maximum likelihood, evolutionary distance, and maximum parsimony methods. Mol. Biol. Evol. 28:2731-2739.

Thompson JD, DG Higgins and TJ Gibson. 1994. Clustal W: improving the sensitivity of progressive multiple sequence alignment through sequence weighting, position-specific gap penalties and weight matrix choice. Nucleic Acids Res. 22:4673-4680.

Womersley HBS and D Sinkora. 1981. Sonderophycus and the 
type specimen of Peyssonnelia australis (Cryptonemiales, Rhodophyta). Trans. R. Soc. S. Aust. 105:85-87.

Yoshida T, Y Nakajima and Y Nakata. 1990. Check-list of marine algae of Japan. Phycol. Res. 38:269-320.

Yoshida T. 1998. Marine algae of Japan. Tokyo: Uchida Roka- kuho Publishing Co., Ltd. pp. 1-1222.

Received: 19 August 2017 Revised: 12 September 2017 Revision accepted: 12 September 2017 